\title{
THE BYZANTINE MILITARY STRATEGY IN ASIA MINOR DURING THE EARLY PALAIOLOGAN PERIOD (1259-1328)
}

\author{
Vladimir A. Zolotovskiy \\ Volgograd State University, Volgograd, Russian Federation
}

\begin{abstract}
Introduction. The purpose of the article is to determine the specifics of the Byzantine war strategy in Asia Minor. A qualitative military and political characteristics of the main military expeditions to the eastern borders are crucial for the disclosure of this problem. From this aspect, the study addresses the following issues: defining of the role of the eastern military campaigns in the complex of military-strategic measures on the state scale; characteristics of the features the armed forces used, as well as the tasks solved during military expeditions to Asia Minor; disclosure of the features of military-technical measures to ensure the security of Byzantium eastern borders. Methods. Critical use of elements of civilizational, formational and systemic approaches is the methodological basis of this study. It should be noted that the use of a systematic approach in the analysis of the Byzantine troops combat practice in east direction, allows to determine the strategic objectives of military expeditions in Asia Minor, to reveal the logic of warfare in the eastern theater, to determine the functional purpose of military-technical measures. Analysis and Results. The study reveals the strategic concept of Byzantium armed forces military operations during the reign of the first Palaeologus on the Asia Minor territory. Analysis of combat practice allows us to conclude that the strategic priority of the western and northwestern directions, which required the use of the most combat-ready troops consisting of mercenaries during the reign of Michael VIII, determined the need to use the Byzantine troops at the eastern borders of the empire. The Byzantine army was episodically involved in major defensive expeditions to the borders of the empire. We determined that the purpose of these campaigns is to stop the advance of enemy armies and their subsequent expulsion from the empire. This logic of military operations does not mean the loss of strategic initiative at the eastern direction. The strategy of passive defense which determined the nature of the military confrontation in the Asia Minor region was ensured by the creation of a garrison system, or a line of fortresses, on the eastern borders of the empire. Fortification activities of Michael VIII and Andronikos II in 1280-1282 temporarily stopped the advance of the Turkish troops. However, natural factors and the intensification of the economic crisis at the end of the $13^{\text {th }}$ century made it impossible to preserve the defensive line located along the banks of the rivers that served as the borders of the Byzantine state. In addition, the strengthening of the military-political power of the emirates of Menteşe, Aydinoglu and Osman led to the loss of the initiative by the Byzantine troops and, as a result, the reduction of the Asia Minor territories of the empire. In an effort to change the situation, Andronicus II proceeded to implement an active defense strategy.
\end{abstract}

Key words: military history of Byzantium, the early Palaeologan period, military organization, war strategy, Asia Minor.

Citation. Zolotovskiy V.A. The Byzantine Military Strategy in Asia Minor During the Early Palaiologan Period (1259-1328). Vestnik Volgogradskogo gosudarstvennogo universiteta. Seriya 4. Istoriya. Regionovedenie. Mezhdunarodnye otnosheniya [Science Journal of Volgograd State University. History. Area Studies. International Relations], 2021, vol. 26, no. 6, pp. 181-193. (in Russian). DOI: https://doi.org/10.15688/jvolsu4.2021.6.16

УДК $94 « 13 / 15 »: 341.321 .3$

Дата поступления статьи: 01.07.2021

ББК 63.3(0)4-93

Дата принятия статьи: 21.12.2021

\section{ВИЗАНТИЙСКАЯ СТРАТЕГИЯ ВОЕННЫХ ДЕЙСТВИЙ В МАЛОЙ АЗИИ В ПЕРИОД ПРАВЛЕНИЯ ПЕРВЫХ ПАЛЕОЛОГОВ}

\section{Владимир Алексеевич Золотовский}

Волгоградский государственный университет, г. Волгоград, Российская Федерация

Аннотация. В рамках исследования раскрыта стратегическая концепция военных действий вооруженных сил Византии в период правления первых Палеологов на территории Малой Азии. Анализ практики 


\section{ВИЗАНТИЙСКОЕ ОБЩЕСТВО И ГОСУДАРСТВО}

боевого применения византийских войск в правление Михаила VIII показал, что особое стратегическое значение западного направления, обеспеченное ударными силами наемного контингента, определило использование ромейских войск на восточных территориях империи. В ходе исследования нами было установлено, что восточное направление военной политики Византии раннепалеологовского периода определялось эффективностью дипломатии. В начале правления Михаил Палеолог состоял в союзнических отношениях с Иконийским султанатом. Однако в процессе усиления политической дезинтеграции в султанате договоренности теряли силу, а грабежи приграничных византийских земель отрядами полунезависимых эмиратов становились основным дестабилизирующим фактором. Используемые на западном направлении ромейские войска лишь эпизодически привлекались в крупномасштабные оборонительные походы на Восток. Основной задачей восточных экспедиций, предпринимаемых после вторжения отрядов противника на византийские земли, была остановка продвижения вражеских войск и их последующее выдворение за пределы империи. Избранная василевсами логика боевой практики соответствует стратегии пассивной обороны, обеспеченной формированием на восточных рубежах Византии сети гарнизонов, или же линии крепостей. Таким образом, для обеспечения обороноспособности императорам было достаточно лишь эпизодически привлекать вооруженные силы для организации походов. Сформированная фортификационная система позволила в 1280 1282 гг. временно остановить продвижение турецких войск. Однако экономический кризис и естественные факторы привели к фактическому уничтожению в конце XIII в. оборонительной линии, расположенной по берегам рек, исполнявших роль границ империи. Рост военного и политического могущества мощи эмиратов (Ментеше, Айдыноглу и Осман) предопределил потерю ромейской армией инициативы. В стремлении исправить ситуацию Андроник II перешел к реализации стратегии активной обороны, мероприятия которой обеспечивалась принятыми на службу наемными отрядами алан и латинян-каталонцев.

Ключевые слова: военная история Византии, раннепалеологовский период, военная организация, стратегия военных действий, Малая Азия.

Цитирование. Золотовский В. А. Византийская стратегия военных действий в Малой Азии в период правления первых Палеологов // Вестник Волгоградского государственного университета. Серия 4, История. Регионоведение. Международные отношения. - 2021. - Т. 26, № 6. - С. 181-193. - DOI: https://doi.org/10.15688/jvolsu4.2021.6.16

Введение. После отвоевания Константинополя и начала восстановления империи возникла необходимость усиления обороноспособности Византии и, как следствие, распределения людских и военных ресурсов Византии в нескольких направлениях.

Основное внимание было объективно уделено западному направлению. Войны балканского и пелопоннесского театров были направлены на нейтрализацию угрозы безопасности столицы. Интенсивность и масштабность военных кампаний были определены особой стратегической концепцией империи, направленной на расширение западных пределов Византии. Такой подход был обеспечен военностратегическими решениями в Малой Азии.

Военные организационно-институциональные мероприятия, а также, собственно, военная политика первых Палеологов на восточном направлении, учеными, посвятившими свои исследования системному обобщению политического и военно-политического опыта империи, оцениваются как поверхностные, ошибочные и вторичные в сравнении с западной политикой [1, с. 285, 295, 299; 34, p. $223 ; 33$, p. 25,$27 ; 36$, p. $452,478-479,491]$. Такая негативная оценка основана на ставшем «общим местом» отрицательном восприятии западных устремлений Михаила VIII. Так, Георгий Пахимер, в ряде пассажей акцентировал внимание на том, что потери владений на востоке империи связаны расширением территории государства на западе [25, vol. I, p. $317^{10-14}$, vol. II, p. $403^{19-20}$ ]. Высказанная мысль современника, видевшего в начале $\mathrm{XIV}$ в. из окон Константинополя убитых турками людей на другом берегу пролива $\left[25\right.$, vol. IV, p. 453 $\left.{ }^{17-24}\right]$, массу мигрировавших из Малой Азии ромеев, заполонивших столицу [25, vol. IV. p. 369 $\left.{ }^{2-11}\right]$, приобретает несколько искаженный смысл относительно периода правления Михаила VIII.

После возвращения столицы и начала восстановления империи Михаил Палеолог столкнулся с необходимостью усиления обороноспособности государства. Самое очевидное средство решения проблемы - укрепление имперской армии - требовало много времени и средств. В этих условиях возросшая в связи с агрессивными действиям латинян угроза без- 
опасности западных рубежей предопределила необходимость концентрации вооруженных сил на европейском направлении. При этом и восточные владения империи не остались без системы сил и средств обеспечения стратегической безопасности.

Цель статьи - определить специфику содержания стратегии военных действий византийской армии в Малой Азии. В достижении цели определяющее значение имеет качественная военно-политическая характеристика основных военных экспедиций к восточным рубежам. В этой связи в исследовании последовательно будут раскрыты следующие вопросы: выделение места восточных военных кампаний в комплексе военно-стратегических мероприятий в общеимперском масштабе; характеристика особенностей применения вооруженных сил, а также задач, решаемых в ходе военных экспедиций в Малую Азию; выделение особенностей военно-технических мероприятий, обеспечивающих безопасность восточных границ Византии.

Методы. Методологическим началом исследования является критическое применение формационного и цивилизационного подходов. Использование системного подхода в совокупности исследовательского инструментария, используемого при анализе практики применения византийских войск на восточном направлении, позволяет определить стратегические задачи военных экспедиций в Малой Азии, выявить логику ведения боевых действий на восточном театре, а также определить функциональное назначение военнотехнических мероприятий. Отметим, что обобщение этих вопросов в контексте использования системного анализа позволяет понять стратегическую концепцию первых Палеологов, определяющую их военную политику.

Анализ. Положение на востоке Византии определялось состоянием отношений с турками. В этой сфере военная политика периода правления Михаила Палеолога базировалась на союзнических договорах никейского периода [9, с. 91-94]. В этой связи надо отметить, что, П. И. Жаворонков связывает активную политику на западном направлении с установлением многолетней стабильности на восточных рубежах после заключения договора между Иконийским султанатом и Никеей в
1216 г. [3, с. 60]. Продолжавшиеся после этого боестолкновения между гази и акритами не влияли на отношения между государствами $[3 \text {, с. } 60 \text {, примеч. 99 }]^{1}$. Кроме того, по мнению Х. Иналджика и Д.А. Коробейникова, гибкая имперская дипломатия, реализуемая на фоне многолетней вражды за власть в султанате, позволяла формировать военные союзы, использовать против турок сельджукских наемников, а также сохранить малоазийские имперские владения вплоть до 1320 гг. [6, с. 457, примеч. $162 ; 28$, p. 78$]$.

Состояние дел на восточных рубежах Византии осложнилась после захвата Ирана Хулагу и начавшейся экспансии во владения Сельджукского султаната. Произошедшее позднее подчинение сельджуков монгольскому Ирану ${ }^{2}$ привело к разрушению властных отношений в султанате. В результате начались катастрофические для всего региона процессы: султанат фактически распался на эмирства - малые политические образования [2, c. 37-38; 20, p. 11-16], вышедшие из-под контроля султана боевые отряды эмиров регулярно предпринимали грабительские рейды в соседние земли [16, с. 4-6]; началась турецкая миграция на Запад [15, с. 148]. Кроме того, военная экспансия Хулагу вынудила Изз альДина Кайкавуса II бежать в Константинополь [25, vol. I, p. $235^{5-10} ; 15$, c. 149$]$.

Михаил VIII оставил султана в империи [25, vol. I. p. $183^{20-25}, 185^{4-21} ; 11$, c. 18]. Однако при этом, учитывая иранский фактор и ущерб от бандитских вылазок турок сельджуков василевс заключил союз с Хулагу [25, vol. I, p. $\left.235^{3-5}, 235^{10-18}\right]$. После его смерти союзнические отношения между Византией и Ираном были скреплены браком Марии, дочери Михаила Палеолога, и хана Абаги, вошедшего на престол в 1265 г. [13, т. III, c. $65 ; 25$, vol. I, p. $\left.235^{18-21}\right]$.

После фактического установления Хулагуидского контроля над сельджукским султанатом определенную угрозу империи представляли отряды неподвластных Руму эмиров (Ментеше, Айдина, Карамана и Гермияна) [26, p. 157]. Их действия носили характер бандитских грабительских вылазок, не угрожавших целостности византийских территорий. Следует согласиться с мнением К. П. Хопвуд о том, что установление союза 


\section{ВИЗАНТИЙСКОЕ ОБЩЕСТВО И ГОСУДАРСТВО}

с султанатом не гарантировало мир с турками [26, p. 156]. Именно в этой связи принципы оборонительной военно-стратегической концепции Византии на Востоке обладали своей спецификой.

Обеспечивая безопасность Малой Азии, Михаил VIII перевел воинов пограничников акритов на более профессиональную основу. Изменения коснулись не только базы материального обеспечения акритов. Для расширения тактических характеристик византийской армии, противостоявшей многочисленным латинским противникам, акриты были включены в состав имперской армии. Это позволило усиливать полевую армию на время западных кампаний за счет мобилизованных отрядов пограничников.

Модернизация военно-тактических функций акритов определялась объективными условиями боя с латинянами. По сообщению Георгия Пахимера, эффективность боеспособности повышалась при использовании латинских контингентов против восточных и восточных воинских формирований против латинян [25, vol. I, p. $273^{1-5}$. По завершению крупномасштабных западных кампаний малоазийские корпуса возвращались на территорию формирования. Отряды фракийцев и македонцев распределялись по гарнизонам или распускались по домам [25, vol. I, p. 121 $21-22$, $151^{9-14}, 285^{3-4}, 295^{13-15}$, vol. III. p. 83 $\left.20-28\right]^{3}$.

После возращения восточные формирования восстанавливали порядок на временно оставшихся без контроля византийских владениях. Как сообщает Пахимер [25, vol. I, p. $\left.285^{19-21}\right]$, Иоанн Палеолог организовал экспедицию малоазийского корпуса своей армии в восточные земли империи в 1263 г. [23, р. 92], после успешного завершения военной кампании против Михаила II [24, p. 149, 154].

Военные походы ромеев к восточным рубежам государства стратегически были связаны активизацией конфликта между Египтом и Румским султанатом. В частности, участившиеся грабительские набеги турецких отрядов были отражением вынужденной под воздействием экспансии мамлюкской армии миграции турецкого населения Рума в более безопасные земли на восточных рубежах Вифинии и Анатолии. Очевидно, что продвижение египетского войска ускорило процесс оттока турок султана в западном направлении - на территорию Византию. Именно их и должны были остановить в 1260-х гг. военные формирования Иоанна Палеолога.

В период с весны по осень 1264 г. армия Иоанна отбросила турецкие отряды, освободив от них земли долины Меандра, города Траллы и Магедон [25, vol. I, p. 289 $20-21,291^{1-9}$ ]. Можно предположить, что войска Иоанна Палеолога предпринимали регулярные рейды против турецких банд, находясь в восточных владениях империи вплоть до следующего западного похода, организованного в 1267 г. [25, vol. I, p. $317^{8-17} ; 23$, p. 92]. По окончании новой западной кампании Иоанн предпринял вторую восточную экспедицию, ставшую не менее успешной чем в 1263-64 гг. Как сообщает Георгий Пахимер турецкие банды покинули Византию только узнав о возвращении Иоанна Палеолога [25, vol. I, p. 317 $\left.17^{17}\right]$.

Последующее вторжение турок в Малую Азию, завершившееся разрушением Тралл ${ }^{4}$, разорением долины Меандра [25, vol. II, p. $\left.591^{30}-593^{1-4}\right]$, было обусловлено стабилизацией внутриполитической ситуации в Руме, нашедшей выражением в усилении власти эмиров, имевших собственные внешнеполитические интересы ${ }^{5}$.

Организованные после смерти Иоанна Палеолога восточные военные кампании основывались на ином принципе. Не имея возможности заменить умершего брата на столь же талантливого и чтимого солдатами полководца, император перешел от активной к пассивной обороне в стратегии обеспечения безопасности от разбойных вылазок турок. Ее основным средством должна была стать линейная фортификационная система, представленная крепостными стенами и засеками, рвами и валами.

Создание такой оборонительной системы в 1280 г. было возглавлено лично Михаилом Палеологом ${ }^{6}$. Очевидно с целью поднятия морального духа населения имперская армия торжественным шествием армии во главе с василевсом появилась на территории бассейна p. Сангарий. Об особой миссии первого этапа восточной кампании Михаила VIII свидетельствует непродолжительность присутствия василевса, который провел в этом районе осень 1280 г., после чего отправился на зимовку в Никею [25, vol. II, p. 623 $\left.3^{13-15}\right]$. 
Второй этап кампании начался весной следующего года $\left[25 \text {, vol. II, p. } 633^{13-17}\right]^{7}$. По сообщению Пахимера, императорским войском была проделана масштабная фортификационная работа: по приказу василевса в местах перехода через реку установили засеки $\left[25\right.$, vol. II, p. $\left.635^{23-33}-637^{1-3}\right]$; постройкой оборонительных стен и их дополнительным усилением малыми крепостями был укреплен берег р. Сангарий [25, vol. II, p. 637 $67^{4-6}$.

Аналогичные мероприятия одновременно с отцом проводили Андроник II и Константин Палеологи [25, vol. II, p. 593 $\left.{ }^{4-11}\right]$. Продвигаясь по р. Меандр экспедиционные силы молодого императора восстанавливали действующие оборонительные укрепления и создавали новые $^{8}$. С учетом масштабности предпринимаемых мероприятий, определенно требующих привлечения значительных людских сил и колоссальных материальных ресурсов, были завершены лишь в 1282 году ${ }^{9}$.

Успешная реализация стратегических задач указанных оборонительных кампаний позволила на продолжительное время оставить малоазийские владения империи на самообеспечении. Однако усилившаяся со временем экспансия турок, вызванная прогрессировавшей раздробленностью в султанате ${ }^{10}$, а также стабилизация положения Византии на Западе обратили внимание василевса к восточным рубежам империи. Здесь важно отметить, что, по мнению X. Иналджика, военные действия турецких армий в «старой приграничной Сельджукидской зоне» носили исключительно разбойный характер вплоть до 20-х гг. XIV века. Исследователь отмечает, что экспансионный стратегический характер в пределах территорий соседних эмиров и Византии действия армий Айядинов и Османов приобретают лишь в конце двадцатых и в тридцатые годы XIV в., [27, p. 228].

Первые самостоятельные мероприятия на востоке империи Андроника II (1289-93 гг.), по содержанию и задачам были отражением действий его отца. Однако предпринятые фортификационные усилия и стремление поднять воинский дух личным присутствием [29, p. 76-79] ${ }^{11}$, не помогли императору остановить миграцию из восточных владений, а также не остановили продвижение турок ${ }^{12}$. Ухудшение положения было обусловлено объективной по- терей функциональной пригодности большей части линейной фортификационной системы. Сообщения Георгия Пахимера об изменении во второй половине 90-х гг. XIII в., береговой линии рек $\left[25\right.$, vol. IV, p. $363^{9-25}, 365^{1-2} ; 7$, c. 291], несущих в себе в качестве фортификационных укреплений засеки или же сплошные крепостные стены, перемежающиеся валами и рвами, позволяют предположить, что именно природные условия определили неэффективность элементов пассивной обороны, совокупность которых с 1280 г. составляла основу функционирования оборонительной стратегической концепции Византии на восточном фронте. По мнению Пахимера, полная беззащитность границ империи перед вторжением турецких отрядов, укрепивших собственную власть эмиров, была обусловлена окончательным уничтожением стихией оборонительных сооружений [25, vol. IV, p. 365 $2-8 ;$ 7, c. 291].

По возвращении с востока в Константинополь в 1293 г. [29, p. 76, note 82] василевс назначил Алексея Филанфропина управителем $(\dot{\eta} \gamma \epsilon \mu \omega \dot{\nu})$ Малой Азии и командующим армией $\left[25 \text {, vol. III, p. } 237^{12-17}\right]^{13}$. Молодой полководец сполна оправдал надежды императора. Как сообщает Пахимер, отеческая щедрость и воинский талант пинкерна позволили ему не только одержать несколько блистательных побед над турками в долине р. Меандра в течение 1294-1295 гг. [25, vol. III, p. 2398-10 ${ }^{14}$, но и побудили отдельные турецкие отряды перейти к нему на службу [25, vol. III, p. $241^{35-36}, 243^{1-2}$ ] (также см.: [31, vol. 1, p. 196 ${ }^{-14} ;$ 12, c. 101-102]. Отметим, что помимо турок, ударная часть войска Алексея Филанфропина была укомплектована критской кавалерией [25, vol. III, p. $237^{19} ; 29$, p. $82-83 ; 18$, p. $26 ; 38$, б. 64].

Успех пинкерна был прерван так называемым «заговором» ${ }^{15}$. По мнению Д. Найкола, после осуждения Филанфропина как предводителя заговорщиков, наемники, служившие ему, были переведены в статус землевладельцев и поселены в Малой Азии [32, p. 131]. Вместе с тем, часть боеспособного войска пинкерна, представленная отрядами турок, продолжала действовать в регионе, но выступая уже против империи [25, vol. III, p. 253 $3-22]$.

После роспуска восточной армии, земли малоазийских территорий остались под защитой пограничных формирований, потерявших 


\section{ВИЗАНТИЙСКОЕ ОБЩЕСТВО И ГОСУДАРСТВО}

боеспособность из-за разрушения системы материального обеспечения от разорения территорий бандитскими вылазками турецких отрядов. Осознавая необходимость сохранения за анатолийскими войсками роли основной оборонительной силы на восточном направлении, император направил на восток Иоанна Тарханиота. С целью усиления обороноспособности восточных границ [25, vol. III, p. 285 22-26] посредством установления административного порядка, а также реорганизации податной системы и системы материального обеспечения, в сентябре 1298 г. ${ }^{16}$ Тарханиот во главе немногочисленного войска прибыл в Малую Азию $\left[25 \text {, vol. III, p. } 285^{19-20}\right]^{17}$. В результате предпринятых мероприятий Тарханиот улучшил материальное положение пограничников

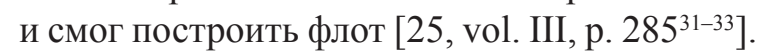

Последующие значимые события на востоке империи произошли в рамках неудачного похода Михаила IX и принятого автократором на службу в 1301 г. аланского корпуса ${ }^{18}$. Точную численность аланского отряда установить невозможно. Опираясь на данные источников, можно предположить, что воинов среди прибывших в Византию алан насчитывалось от восьми [25, vol. IV, p. 33727-29] до десяти тысяч [31, vol. 1, p. $204^{14-21}$. Не менее неопределенным остается вопрос об их этнической и конфессиональной принадлежности.

Подчеркнем, что гипотеза М. Бартусиса о том, что большая часть алан была представлена крещеными турками, видится безосновательной $[19$, р. 76]. Вместе с тем заслуживает внимания неоднократно упомянутый в историографии тезис о том, что этот отряд воинов, обозначенный в источниках общим этнонимом - аланы, являлся одним из многочисленных отрядов, составлявших армию Ногая, находившегося после его смерти под командованием Джеки. После его убийства воины были вынуждены искать нового «покровителя», которым стал Андроник II.

Определенно можно сказать, что этнический состав «аланского корпуса» был крайне неоднородным. При этом следует указать, что фрагмент «Истории» Пахимера, в котором автор определенно сообщал о руссах, аланах, турках и проч. в составе армии Ногая $\left[25\right.$, vol. II, p. $\left.445^{15-18}\right]$, явно свидетельствует о том, что историк имел четкое представление об этническом различии, и в случае полиэтничности прибывшего войска, не упустил бы возможности это отметить.

Аланское войско было разделена на два отряда ${ }^{19}$ : один - передан под командование этериарха Музалона и направлен в район Никомидии, против турецких войск Османа [25, vol. IV, p. 339 26-29], второй - под управлением Михаила IX отправился в поход к югу от Магнезии против Ментеше [25, vol. IV, p. 33929-30].

Отряд Музалона, потерпев сокрушительное поражение в первом же столкновении у Бафии 27 июля 1302 г. [25, vol. IV, p. 358, note 40; 29, p. 90-91 note 14] ${ }^{20}$, был вынужден отойти к Никомидии [25, vol. IV, p. $359^{4-7}$, $\left.365^{8-32}, 367^{1-19}\right]^{21}$. Основываясь на данных османской литературы, Х. Иналджик датировал это сражение, произошедшее у крепости Койан-Хисари [28, p. 93-94] летом (вероятно, 27 июля) 1301 г. [28, p. 97]. Объясняя действия армии Османа у Бафии, историк акцентировал внимание на экономическом и военном приоритете Никеи, находящейся на стратегически важном пути передвижения военных сил и торговых караванов по Малой Азии. Именно в этой связи по приказу Османа вблизи от Никеи была построена крепость, ставшая турецким опорным пунктом в рейдах к хорошо укрепленному городу [28, p. 83-84].

Провалом закончился и поход Михаила IX против эмира Ментеше. Находившись продолжительное время в расположении лагеря, после первых же грабительских вылазок турок Михаил Палеолог принял решение об отступлении и укрытии в Магнезии. Начавшееся отступление ромеев, после непродолжительной атаки противников, превратилось в бегство без вступления в бой [25, vol. IV, p. $\left.343^{29-36}, 345^{1-2}\right]$. Укрывшись в Магнезии, Михаил IX Палеолог [25, vol. IV, p. $\left.345^{8-9}\right]$ сохранил на службе аланский отряд, планируя направить его против турок. Однако, не получил довольствия за три месяца, аланы покинули расположение молодого василевса и переправились на Галлиполи [25, vol. IV, p. $347^{15-16}, 351^{3-6}$. Сам же Михаил IX с небольшим отрядом охраны бежал в укрепленный Пергам [25, vol. IV, p. 347 $\left.16-22,349^{7-10}\right]^{22}$.

Понесенные империей поражения от войск Ментеше и Османа означали окончательное разрушение действовавшей ранее 
системы обороны и открыли противниками Византии во все малоазийские владения. Как следствие, уже в 1304 г. армии Саса-бея и Айдиноглу захватили Эфес [30, p. 20-25; 37, S. 39-41], а к 1305 г. турецкие формирования захватили западное малоазийское побережье, за исключением Фокеи и Адрамития [30, p. 24, 50].

Ситуация на восточных рубежах Византии была временно стабилизирована наемным каталонским войском ${ }^{23}$. Весной 1304 г. наемники Рожера де Флора сокрушили войска Айдыноглу (отряды (габеллы) «Сеза и Тию») у Филадельфии [21, ch. CCV, p. 423; 25, vol. IV, p. $\left.469^{15-30}, 471^{1-6}\right]$. После освобождения пригорода отряды каталонцев выдвинулись на юг и отвоевали у турок Тиру [21, ch. CCVI, p. 424], Анию [21, ch. CCVI, p. 424] ${ }^{24}$ и Эфес [21, ch. CCVII, p. 425-426; 25, vol. IV, p. 479 ${ }^{23-24}{ }^{25}$. По сообщению Рамона Мунтанера, кампания прошла по территории Малой Азии вплоть до «железных врат» гор Тавра в Армении ${ }^{26}$. После завершения успешного похода наемное войско де Флора развернулось к г. Магнезии ${ }^{27}$, захваченному Атталиатом [25, vol. IV, p. $471^{1327}$. Атталиат, возглавил городское восстание, организованное жителями против каталонцев - грабителей и разбойников, обращавшихся с «населением как с рабами» [25, vol. IV, p. $471^{27-30}$. По возвращении каталонцы подавили восстание, с частью участников жестоко расправившись, а другую наказав материальными взысканиями $\left[25 \text {, vol. IV, p. } 527^{20-25}\right]^{28}$.

Итак, несмотря на последствия для местного населения, пятимесячная «восточная кампания〉 наемников закончилась не только возвращением империи земель в пределах зоны Меандр - Сангарий, но и вынудила турецкие отряды отступить глубоко на территорию Малой Азии.

Отметим, что не все исследователи военной истории поздней Византии положительно оценивают действия каталонцев. В частности, М. Бартусис подчеркнул, что немногочисленность каталонского контингента предопределила действия наемников в отношении отвоеванных городов. По мнению исследователя, после освобождения городов каталонцы их покидали, не оставляя и не усилия в них гарнизонов. Как следствие оставшиеся незащищенными после отбытия наемников территории вскоре вновь были захвачены турками. Таким образом историк обосновывал смой тезис о нерезультативности действий каталонцев для Византии [19, p. 79].

Точка зрения, высказанная М. Бартусисом, представляется ошибочной. Вполне очевидно, что опытная армия профессиональных воинов знала обо всех формах и средствах укрепления обороноспособности и сохранения захваченных территорий. Об этом, в частности, свидетельствует факты удержания крепостей, в том числе многочисленными гарнизонами, в течение длительного времени.

Кроме того, по данным Георгия Пахимера каталонские гарнизоны были сформированы в отвоеванных наемниками в Анатолии и Вифинии крепостях. В частности, в сообщении о предательстве каталонцев в Кудукее, историк упоминает о том, что «кесарь (Рожер де ФлорВ.3.) оставил здесь для охраны незначительное количество воинов» $\left[25\right.$, vol. IV, p. $\left.635^{18-20}\right]$. Детали повествования о последовавших событиях определенно указывают на то, что гарнизон крепости был усилен сто двадцатью альмугаварами [25, vol. IV, p. 635 23-24].

По вопросу о потерях территорий после передислокации наемных отрядов необходимо обратить внимание на выражения Рамона Мунтанера, указавшего, что к концу 1304 г. Рожер де Флор фактически был владельцем всей Анатолии, захваченной его армией [21, ch. CCIX. p. 427]. Аналогичное сообщение мы встречаем и у Пахимера, отметившего что Рожер оставлял стражу в восточных владениях поскольку считал «землю своей, по воле василевса» [25, vol. IV, p. 635 $\left.5^{19-21}\right]$.

В завершении следует заметить, что экспансия турок в восточных землях Византии по ряду внутриполитических причин прекратилась ${ }^{29}$ вплоть до периода фактического правления Андроника III [27, p. 228], установленного еще в разгар гражданской войны ${ }^{30}$.

Результаты. Подводя итоги исследования, необходимо остановиться на следующих положениях. Постоянный характер боестолкновений с отрядами турок был обусловлен начавшейся в Румском султанате политической раздробленностью.

Независимо от политики султана малые турецкие отряды, выступавшие ударной силой эмирств, совершали регулярные разорительные 


\section{ВИЗАНТИЙСКОЕ ОБЩЕСТВО И ГОСУДАРСТВО}

набеги на приграничные земли империи. Наносимый ими ущерб хозяйству и экономики византийских территорий существенно ослаблял боеспособность восточных формирований провинциальной армии. В таких условиях единственным средством сдерживания угрозы безопасности в период правления Михаила VIII стала оборонительная система, представленная фортификационными линиями и сетью гарнизонов. В особых случаях обороноспособность системы усиливалась организацией крупномасштабных военных экспедиций, направленных на выдворение противника за рубеж государства.

Существенное изменение внешнеполитической ситуации на восточном направлении произошло в результате обретения турецкими эмиратами большей самостоятельности. Стремление к установлению контроля над Малоазийским полуостровом подкрепленное формирование многочисленных армий позволило некоторым эмирам начать территориальную экспансию. В результате уже в конце XIII - начале XIV в. Византия потеряла часть восточных земель.

Изменение стратегической ситуации, безусловно, делало необходимым пересмотр структуры и содержания имперской оборонительной системы. Однако византийская фортификационная линия так и не была восстановлена после ущерба, нанесенного ей природной стихией. Таким образом, только система укрепленных поселений и крепостей позволяла обеспечивать контроль над путями передвижения по владениям империи на полуострове. Усиление ее боеспособности при масштабной военной угрозе обеспечивалось организацией крупных военных походов полевой армии Византии. В соответствии со стратегией активной обороны в правление Андроника II к службе привлекались крупные воинские формирования наемников.

\section{ПРИМЕЧАНИЯ}

${ }^{1}$ О столкновениях акритов и гази (данышмедов) см.: [37, S. 5-6].

${ }^{2}$ По мнению К. Каэн, именно после Хулагу хана в истории сельджуков начинается эпоха подданничества [20, р. 275-278].

${ }^{3}$ Об использовании восточных формирований на западном направлении прямо сообщается в сочинении Георгия Пахимера [25, vol. II, p. 403 ${ }^{9-16}$ ].
${ }^{4}$ В частности, Георгий Пахимер сообщает о разрушенном городе на берегу Меандра [25, vol. II, p. $\left.593^{11-14}\right]$

${ }^{5}$ Георгий Пахимер связывает продвижение турок в глубь Анатолии со смертью Иоанна Палеолога [25, vol. II, p. 59127-29].

${ }^{6}$ По мнению А. Файе Михаил Палеолог организовал три отдельные похода: первый был предпринят осенью 1280 г., второй - весной 1281 г., третий - осенью 1281 г. [24, р. 242-247].

7 Учитывая известные нам данные об автократоре в проведении Елеосвящения, полагаем, что второй этап восточной кампании был начат после возвращения Михаила VIII из столицы и пришелся период не ранее конца апреля - начала мая 1281 г.

${ }^{8}$ О восстановлении г. Траллы сообщает Пахимер [25, vol. II, p. 593 $\left.14-23-595^{1-11}\right]$. Необходимость периодического обновления объектов линейной фортификационной системы подтверждается данными Георгия Пахимера о разрушении засек и крепостей в периоды разливов рек. Перевод соответствующего фрагмента «Истории» с подробным комментарием, см. в работе Д.А. Коробейникова [7, с. 288, примеч. 6].

${ }^{9}$ O роли созданных Михаилом VIII и Андроником II укреплений в оборонительной стратегии свидетельствуют данные современника, определенно подчеркнувшего связь разрушения укреплений по р. Меандр и р. Сангарий с вторжением турецких отрядов в империю. Перевод соответствующего фрагмента «Истории» Пахимера, см. в работе Д. А. Коробейникова [7, с. 291].

${ }^{10}$ По мнению Э. Арвейлер возвращение Константинополя в 1261 г. послужило отправной точкой в череде событий, определивших потерю империей восточных земель [17, p. 230]. Историк полагает, что вынужденная с целью обеспечения безопасности Константинополя переориентация военной политики на западное направление, обеспеченная в правление Михаила Палеолога концентрацией военных и невоенных ресурсов, позволила укрепить позиции отдельных эмиров и расширить их присутствие на восточных землях Византии. Как следствие уже в первое двадцатилетие XIV в. эмиром Саруханом были практически полностью завоеваны Лидия и Эгейское побережье. В то же время к Айдыноглу отошли Ионическое побережье с большей частью Смирны и г. Эфес [17, p. 210].

${ }^{11}$ На анализе письменного наследия Феодора Метохита исследователь реконструировала идеологическое основание, причины и ход этой экспедиции императора [29, p. 78-79, note 87-93].

${ }^{12} \mathrm{O}$ большом количестве беженцев с восточных территорий в столице в начале XIV в. сообщил Георгий Пахимер [25, vol. IV, p. 369-11 $453^{17-24} ; 18$, p. $28 ; 19$, p. 73$]$. 
13 Эти земли и фема Неокастрон контролировал протовестиарий Ливадарий [25, vol. III, p. $\left.237^{17-18}\right]$.

${ }^{14}$ Косвенным подтверждением успеха византийских войск является снижение цены на рабов пленных турок, в результате из многочисленности $[19$, p. $74 ; 29$, p. 82 , note $99 ; 14$, c. 170$]$.

${ }^{15}$ По данным Георгия Пахимера, инициатива установления суверенной власти Алексея Филанфропина исходила от недовольных малым

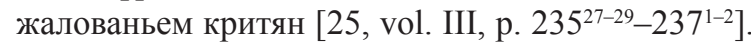
Подробнее о военной кампании под руководством Филанфропина, в контексте текстологического анализа эпистолярного наследия, см.: [10].

${ }^{16}$ На основе датировки писем патриарха Афанасия, А. Лайу определила начало экспедиции Тарханиота сентябрем 1298 г. [29, p. 87, note 4].

${ }^{17}$ Авторы PLP в статье посвященной Тарханиоту предположили, что главной целью его похода было выступление против армии Османа. Этот тезис представляется сомнительным не только исходя из вполне определенных целей похода, обоснованных исключительно финансовыми интересами Византии, но и, объективно, более поздним появлением турецких отрядов под командованием Османа.

${ }^{18}$ Ю. Кулаковский полагал, что прибывшее в 1300 г. после смерти Джеки в империю десятитысячное войско алан, составляло часть населения улуса, расселенная к северу от нижнего Дуная [8, c. 66-67]. Предположение историка частично подтверждается сообщением Рукн-ад-дина Бейбарса: «Он (Джека) отправился в страну Асов, в которой находился предводитель и 10000 войска его» [5, c. 116].

${ }^{19}$ Мнение М. Бартусиса о разделении аланского корпуса на три группы противоречит данным источников и представляется необоснованным $[19$, p. 76].

${ }^{20}$ Обвинение М. Бартусисом алан в дезертирстве с момента прибытия в Вифинию не подтверждается источниками [19, р. 76]. Опираясь на данные источников, можно сделать о том, что отряд наемников-алан обладал большей силой воинского духа и преданностью делу, нежели ромеи. В частности, согласно сообщению Георгия Пахимера, именно аланы защищали Никомидию, прикрывая войско Музалона, вступившего в столкновение с многотысячной армией эмира Вифинии Османа [25, vol. IV, p. $\left.367^{3-29}\right]$.

${ }^{21}$ По мнению А. Лайу, захват турками малоазийских территорий империи стал следствием неудачной политики Андроника II и Андроника III обусловили переход малоазийских территорий Византии под полный контроль турок. При этом захват в 1390 г. Филадельфии воспринят истори- ком как победоносное окончание турецкой экспансии [29, р. 25].

22 Учитывая данные о последующем участии алан в военных действиях можно согласиться с мнением М. Бартусиса о том, что после непродолжительной службы большая часть алан, сдавших вооружение и вернувших украденных (? - B. 3.) лошадей, были выселены из империи [19, p. 77].

${ }^{23}$ История каталонской кампании в Византии представляет особый интерес в научной литературе и не входит в предметное поле нашего изыскания.

${ }^{24}$ Важно отметить, что сообщения Георгия Пахимера об освобожденных каталонцами городах включены в описание зверств наемников по отношению к ромеям [25, vol. IV, p. 4797-27]. Можно предположить, что таким образом историк пытался подчеркнуть отрицательное отношение к военным успехам каталонцев, заслуги которых меркнут перед ущербом, нанесенным византийскому населению.

${ }^{25}$ Согласно хронологии Энвери, можно сделать вывод о том, что отвоеванный в 1304 г. каталонцами Эфес позднее был вновь захвачен турками Айдыноглу. Некоторое время спустя византийцы совместно с латинянами (очевидно, генуэзцами), аланами, турками и сербами попытались отвоевать города $\left[22\right.$, р. $\left.46^{23}-47^{36}\right]$. Как полагает К.А. Жуков, уход каталонцев с восточных территорий позднее был воспет в поэме Энвери как победа [4, с. 26].

${ }^{26}$ По данным каталонского хрониста битва с турками у гор Тавра произошла «в день святой Марии в августе» [21, ch. CCVII, p. 426].

${ }^{27}$ Рамон Мунтанер упоминает о Магнезии единожды, в сообщении о передвижении наемников после освобождения Филадельфии [21, ch. CCV, p. 423]. Вместе с тем Георгий Пахимер сообщает о Магнезии как городе - казне каталонцев на время «анатолийской кампании» [25, vol. IV, p. 4837-11].

${ }^{28}$ В августе-сентябре каталонцы подавили восстание в Магнезии. После этого они отправились в Галлиполи, вделав его на последующие 2-3 года своим опорным пунктом [25, vol. IV, p. 527 ${ }^{25-26} ; 21$, ch. CCXIV. p. 433; 29, p. 135-137; 32, p. 136-138].

${ }^{29}$ Известные захваты Эфеса в 1304 г. войсками Айдыноглу, а после ухода из Малой Азии каталонцев - войсками Саса-бея, в 1313 г. Магнезии (Магнисии) - войсками Сарухан-бея, зимой 1315-1316 гг. войсками Али-паши Нимфея не означали полного захвата малоазийских территорий Византии, а лишь свидетельствовали о продвижении турецких отрядов по Эгейскому побережью Малой Азии.

${ }^{30}$ По мнению Н. Икономидиса, противостояние эмиров Саса-бея и Айдыноглу началось задолго до 1312-1313 гг. [35, р. 167]. 


\section{СПИСОК ЛИТЕРАТУРЫ}

1. Васильев, А. А. История Византийской империи : От начала Крестовых походов до падения Константинополя / А. А. Васильев / вступ. ст., примеч., науч. ред., пер. с англ. яз. и имен. указ. А. Г. Грушевого. - СПб. : Алетейя, 2000. - 581 с.

2. Гордлевский, В. А. Государство сельджуков Малой Азии / В. А. Гордлевский. - М. ; Л. : Изд-во Акад. наук СССР, 1941. - 200 с.

3. Жаворонков, П. И. Никейско-латинские и никейско-сельджукские отношения в 1211-1216 гг. / П. И. Жаворонков // Византийский временник. 1976. - Т. 37. - С. 48-61.

4. Жуков, К. А. Эгейские эмираты в XIVXV вв. / К. А. Жуков. - М. : Наука, 1988. - 192 с.

5. Из летописи Рукн-ад-Дина Бейбарса / Рукн-ад-Дин Бейбарс // Тизенгаузен, В. Сборник материалов, относящихся к истории Золотой Орды. Т. 1 : Извлечения из сочинений арабских / В. Тизенгаузен. - СПб. : Тип. Императорской Академии наук, 1884. - С. 82-123.

6. Коробейников, Д. А. Византия и государство Ильханов в XIII-начале XIV вв. : Система внешней политики империи / Д. А. Коробейников // Византия между Западом и Востоком : Опыт исторической характеристики. - СПб. : Алетейя, 1999. - С. 428-473.

7. Коробейников, Д. А. Из $\Sigma v \gamma \gamma \rho а ф \iota \kappa \omega \widetilde{\nu}$

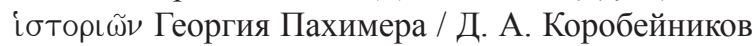
// Византийский временник. - 2000. - Т. 59 (84). C. 288-292.

8. Кулаковский, Ю. А. Аланы по сведениям классических и византийских писателей / Ю. А. Кулаковский. - Киев : Тип. Имп. ун-та св. Владимира Н. Т. Корчак-Новицкого, 1899. - IV, 73 с.

9. Лебедев, Н. Византия и Монголы в ХІІІ в. : (По известиям Георгия Пахимера) / Н. Лебедев // Исторический журнал. - 1944. - Кн. 1. - С. 91-94.

10. Лысиков, П. И. Письма Максима Плануда к Алексею Филанфропину и Мелхиседеку Акрополиту : Проблемы источниковедения в контексте военно-политической ситуации в Византии в конце XIII века / П. И. Лысиков // Вестник Волгоградского государственного университета. Серия 4, История. Регионоведение. Международные отношения. 2017. - T. 22, № 5. - C. 271-287. - DOI: https://doi. org/10.15688/jvolsu4.2017.5.25.

11. Павлов, П. България, Византия и Мамлюкски Египет през 60-те-70-те години на XIII в. / П. Павлов // Исторически преглед. - 1989. Књ. 3. - С. 15-24.

12. Радић, Р. Византијски војсковоћа Алексије Филантропин / Р. Радић // Зборник радова византолошког института. - 1998. - Књ. XXXVII. C. 97-109.
13. Рашид-ад-Дин. Сборник летописей. В 3 т. Т. 3 / отв. ред. С. П. Толстов. - М. : Ладомир, 2002. $340 \mathrm{c}$.

14. Шамгунова, Т. А. Восприятие войны с варварами византийским монахом / Т. А. Шамгунова // Мир Православия. - 2006. - Вып. 6. C. $167-173$.

15. Шукуров, Р. М. Тюрки в византийском мире (1204-1461) / Р. М. Шукуров. - М. : Изд-во Московского ун-та, 2017. - 631 с.

16. Эмеджен, Ф. От создания Османского государства до Кючук-Кайнарджийского договора / Ф. Эмеджен // История Османского государства, общества и цивилизации : в 2 т. Т. 1 : История Османского государства и общества / под ред. Э. Ихсаноглу ; пер. В. Б. Феоновой под ред. М. С. Мейера. - М. : Вост. лит., 2006. - С. 3-50.

17. Ahrweiler, H. La frontière et les frontières de Byzance en Orient / H. Ahrweiler // Actes du XIV Congrès international des études byzantines. Bucarest, 6-12 septembre 1971. Vol. 1. - Bucureşti : Editura Academiei Republicii Socialiste România, 1974. P. 209-230.

18. Ahrweiler, H. L'histoire et la géographie de la région de Smyrne entre les deux occupations turques (1081-1317), particulièrement au XIII ${ }^{\mathrm{e}}$ siecle / H. Ahrweiler // Ahrweiler, H. Byzance : Les pays et les territories / H. Ahrweiler. - London : Variorum Reprints, 1976. - P. 1-204.

19. Bartusis, M. C. The Late Byzantine Army : Arms and Society, 1204-1453 / M. C. Bartusis. Philadelphia : University of Pennsylvania Press, 1992. - XVII, 438 p.

20. Cahen, C. Pre-Ottoman Turkey : A General Survey of the Material and Spiritual Culture and History c. 1071-1330 / transl. by J. Jones-Williams / C. Cahen. New York : Taplinger Pub. Co., 1968. - XX, 458 p.

21. Chronique du très magnifique seigneur Ramon Muntaner // Chroniques étrangères relatives aux expéditions françaises pendant le XIII ${ }^{\mathrm{e}}$ siècle / publ., élucid. et trad. par J. A. C. Buchon. - Paris : A. Desrez, 1840. - P. 217-564.

22. Düstūrnāme-ì Enverī. Le Destān d'Umūr Pacha Osmanlı tarihi kısmı, 1299-1465 / texte, trad. et notes par I. Mélikoff-Sayar. - Paris : Presses Universitaires de France, 1954. - 155 p.

23. Failler, A. Chronologie et composition dans l'histoire de Georges Pachymère / A. Failler // Revue des études byzantines. - 1980. - T. 38. - P. 5-103.

24. Failler, A. Chronologie et composition dans l'histoire de Georges Pachymère / A. Failler // Revue des études byzantines. - 1981. - T. 39. - P. 145-249.

25. Georges Pachymérès. Relationes historiques / éd. par A. Failler, V. Laurent. - Vol. I : Liv. I-III. Paris : Les belles lettres, 1984. - 325 p. ; Vol. II : Liv. IV-VI. - Paris : Les belles lettres, 1984. - P. 328- 
667 ; Vol. III : Liv. VII-IX. - Paris : Inst. fr. d'ét. byz., 1999. - 305 p. ; Vol. IV : Liv. X-XIII. - Paris : Inst. fr. d'ét. byz., 1999. - P. 306-727.

26. Hopwood, K. R. The Byzantine - Turkish Frontier, c. 1250-1300 / K. R. Hopwood // Acta Viennensia Ottomanica : Akten des 13. CIEPOSymposiums. - Wien : Selbstverlag des Instituts für Orientalistik, 1999. - P. 153-161.

27. Inalcik, H. The Ottoman Turks and the Crusades, 1329-1522 / H. Inalcik // A History of the Crusades. Vol. VI / ed. K. M. Setton. - Madison : University of Wisconsin Press, 1989. - P. 222-275.

28. Inalcik, H. Osman Ghazi's Siege of Nicaea and the Battle of Bapheus / H. Inalcik // The Ottoman Emirate : 1300-1389 / ed. E.A. Zachariadou. - Rethymnon : Crete University Press, 1993. - P. 77-99.

29. Laiou, A. Constantinople and the Latins : The Foreign Policy of Andronicus II, 1282-1328/ A. Laiou. - Cambridge (Mass.) : Harvard University Press, 1972. - XII, $390 \mathrm{p}$.

30. Lemerle, P. L'Emirat d'Aydin : Byzance et l'Occident / P. Lemerle. - Paris : Presses universitaires de France, 1957. - 276 p.

31. Nicephori Gregorae Byzantina historia : in 3 vols. Vol. 1. - Bonn : Weber, 1829. - C, 568 p.

32. Nicol, D. M. The Last Centuries of Byzantium, 1261-1453 / D. M. Nicol. - London : Hart-Davis, 1972. - P. XII, 482.

33. Nicol, D. M. The End of the Byzantine Empire / D. M. Nicol. - London : E. Arnold, 1979. - 109 p.

34. Nicol, D. M. Byzantium and Venice : A Study in Diplomatic and Cultural Relations / D. M. Nicol. Cambridge ; New York : Cambridge University Press, 1988. - X, 465 p.

35. Oikonomidès, N. The Turks in Europe (1305-13) and the Serbs in Asia Minor (1313)/ N. Oikonomidès // The Ottoman Emirate : 1300 1389 / ed. E. A. Zachariadou. - Rethymnon : Crete University Press, 1993. - P. 159-168.

36. Ostrogorsky, G. History of the Byzantine State / G. Ostrogorsky ; transl. from the German by Joan Hussey ; with a foreword by Peter Charanis. - New Brunswick, N. J. : Rutgers University Press, 1969. XL, $624 \mathrm{p}$.

37. Wittek, P. Das Fürstentum Mentesche. Studie zur Geschichte Westkleinasiens im 13-15. Jahrhunderts / P. Wittek. - Istanbul : Universum Druckerei. 1934. - XIV, $192 \mathrm{~S}$.

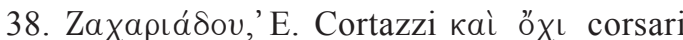

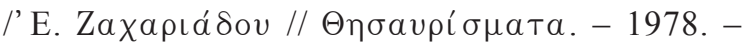
T. $15 .-\sum .62-65$.

\section{REFERENCES}

1. Grushevoy A.G., ed. Vasilev A.A. Istoriya Vizantiyskoy imperii: Ot nachala Krestovykh pokhodov do padeniya Konstantinopolya [History of the Byzantine Empire: From the Beginning of the Crusades to the Fall of Constantinople]. Saint Petersburg, Aletheia Publ., 2000. 581 p.

2. Gordlevskij V.A. Gosudarstvo seldzhukov Maloy Azii [The Seljuk State of Asia Minor]. Moscow; Leningrad, Izd-vo Akad. nauk SSSR, 1941. 200 p.

3. Zhavoronkov P.I. Nikeysko-latinskie i nikeysko-seldzhukskie otnosheniya v 1211-1216 gg. [Nicene-Latin and Nicene-Seljuk Relations in 12111216]. Vizantiiskii vremennik [Byzantina Chronika], 1976, vol. 37, pp. 48-61.

4. Zhukov K.A. Egeyskie emiraty $v X I V-X V v v$. [Aegean Emirates in the $14^{\text {th }}-15^{\text {th }}$ Centuries]. Moscow, Nauka Publ., 1988. 192 p.

5. Iz letopisi Rukn-ad-Dina Beybarsa [From the Annals of Rukn al-Din Baibars]. Tizengauzen V. Sbornik materialov, otnosyashchikhsya k istorii Zolotoy Ordy. T. 1: Izvlecheniya iz sochineniy arabskikh [Collection of Materials Related to the History of the Golden Horde. Vol. 1: Extracts from Arabic Papers]. Saint Petersburg, Tip. Imperatorskoy Akademii nauk, 1884, pp. 82-123.

6. Korobeynikov D.A. Vizantiya i gosudarstvo Ilkhanov v XIII - nachale XIV vv.: Sistema vneshney politiki imperii [Byzantium and the Ilkhan State in the $13^{\text {th }}-$ Early $14^{\text {th }}$ Centuries: The System of the Empire Foreign Policy]. Vizantiya mezhdu Zapadom $i$ Vostokom: Opyt istoricheskoy kharakteristiki [Byzantium Between West and East: An Experience of Historical Characteristics]. Saint Petersburg, Aletheia Publ., 1999, pp. 428-473.

7. Korobeynikov D.A. Iz Syngraphikon istorion Georgiya Pakhimera [From Syngraphikon istorion of George Pachymeres]. Vizantiiskii vremennik [Byzantina Chronika], 2000, vol. 59 (84), pp. 288-292.

8. Kulakovskiy Yu.A. Alany po svedeniyam klassicheskikh i vizantiyskikh pisateley [Alans According to the Information of Classical and Byzantine Writers]. Kiev, Tip. Imp. universiteta of sv. Vladimira N.T. Korchak-Novitskogo, 1899. 73 p.

9. Lebedev N. Vizantiya i Mongoly v XIII v. (Po izvestiyam Georgiya Pakhimera) [Byzantium and Mongols in the XIII Century (According to George Pachymeres]. Istoricheskiy zhurnal [Historical Journal], 1944, vol. 1, pp. 91-94.

10. Lysikov P.I. Pisma Maksima Planuda k Alekseyu Filanfropinu i Melkhisedeku Akropolitu: Problemy istochnikovedeniya v kontekste voennopoliticheskoy situatsii v Vizantii v kontse XIII veka [The letters of Maximos Planudes to Alexios Philanthropenos and Melchisedek Akropolites: The Problems of Source Studies in the Context of the Politico-Military Situation in Byzantium in the Late $13^{\text {th }}$ C.]. Vestnik Volgogradskogo gosudarstvennogo universiteta. Seriya 4. Istoriya. Regionovedenie. 
Mezhdunarodnye otnosheniya [Science Journal of Volgograd State University. History. Area Studies. International Relations], 2017, vol. 22, no. 5, pp. 271-287. DOI: https://doi.org/10.15688/ jvolsu4.2017.5.25.

11. Pavlov P. Balgariya, Vizantiya i Mamlyukski Egipet prez 60-te-70-te godini na XIII v. [Bulgaria, Byzantium and the Mamluk Egypt in the 60s-70s of the $13^{\text {th }}$ Century]. Istoricheski pregled [Historical Review], 1989, vol. 3, pp. 15-24.

12. Radih R. Vizantijski vojskovoća Aleksije Filantropin [Byzantine Military Leader Alexius Philanthropin]. Zbornik radova vizantološkog instituta, 1998, vol. 37, pp. 97-109.

13. Tolstov S.P., ed. Rashid-ad-Din. Sbornik Letopisey [Rashid al-Din. Collection of Chronicles]. In 3 vols. Vol. 3. Moscow, Ladomir Publ., 2002. 340 p.

14. Shamgunova T.A. Vospriyatie voyny $\mathrm{s}$ varvarami vizantiyskim monakhom [Perception of War against the Barbarians by a Byzantine Monk]. Mir Pravoslaviya [The World of Orthodoxy], 2006, vol. 6, pp. 167-173.

15. Shukurov R.M. Tyurki v vizantiyskom mire (1204-1461) [The Byzantine Turks, 1204-1461]. Moscow, Izd-vo Mosk. un-ta, 2017. 631 p.

16. Emedzhen F. Ot sozdaniya Osmanskogo gosudarstva do Kyuchuk-Kaynardzhiyskogo dogovora [From the Creation of the Ottoman State to the Treaty of Küçük Kaynarca]. Ikhsanoglu E., Feonova V.B., Meyer M.S., eds. Istoriya Osmanskogo gosudarstva, obshchestva i tsivilizatsii: v 2 t. T. 1: Istoriya Osmanskogo gosudarstva i obshchestva [History of the Ottoman State, Society and Civilization. In 2 vols. Vol. 1: History of the Ottoman State and Society]. Moscow, Vost. lit. Publ., 2006, pp. 3-50.

17. Ahrweiler $\mathrm{H}$. La frontière et les frontières de Byzance en Orient. Actes du XIV Congrès international des études Byzantines, Bucarest, 6-12 septembre 1971. Vol. 1. Bucurešti, Editura Academiei Republicii Socialiste România, 1974, pp. 209-230.

18. Ahrweiler H. L'histoire et la géographie de la région de Smyrne entre les deux occupations turques (1081-1317), particulièrement au XIII ${ }^{\mathrm{e}}$ siecle. Ahrweiler H. Byzance: les pays et les territories. London, Variorum Reprints, 1976, pp. 1-204.

19. Bartusis M.C. The Late Byzantine Army: Arms and Society, 1204-1453. Philadelphia, University of Pennsylvania Press, 1992. XVII, 438 p.

20. Jones-Williams J., ed. Cahen C. Pre-Ottoman Turkey: a General Survey of the Material and Spiritual Culture and History c. 1071-1330. New York, Taplinger Pub. Co., 1968. XX, 458 p.

21. Chronique du très magnifique seigneur Ramon Muntaner. Buchon J.A.C., ed. Chroniques étrangères relatives aux expéditions françaises pendant le XIII' siècle. Paris, A. Desrez, 1840, pp. 217-564.
22. Mélikoff-Sayar I., ed. Düstūrnāme-ì Enverī. Le Destān d'Umūr Pacha Osmanlı tarihi kısmi, 1299-1465. Paris, Presses Universitaires de France, 1954. 155 p. 23. Failler A. Chronologie et composition dans l'histoire de Georges Pachymère. Revue des études byzantines, 1980, vol. 38, pp. 5-103.

24. Failler A. Chronologie et composition dans l'histoire de Georges Pachymère. Revue des études byzantines, 1981, vol. 39, pp. 145-249.

25. Failler A., Laurent V., eds. Georges Pachymérès. Relationes historiques. Vol. I: Liv. I-III. Paris, Les belles lettres, 1984. 325 p.; Vol. II: Liv. IV-VI. Paris, Les belles lettres, 1984, pp. 328-667; Vol. III: Liv. VII-IX. Paris, Inst. fr. d'ét. byz., 1999. 305 p.; Vol. IV: Liv. X-XIII. Paris, Inst. fr. d'ét. byz., 1999, pp. 306-727.

26. Hopwood K.R. The Byzantine - Turkish Frontier, c. 1250-1300. Acta Viennensia Ottomanica: Akten des 13. CIEPO-Symposiums. Wien, Selbstverlag des Instituts für Orientalistik, 1999, pp. 153-161.

27. Inalcik H. The Ottoman Turks and the Crusades, 1329-1522. Setton K.M., ed. A History of the Crusades. Vol. VI. Madison, University of Wisconsin Press, 1989, pp. 222-275.

28. Zachariadou E.A., ed. Inalcik H. Osman Ghazi's Siege of Nicaea and the Battle of Bapheus. The Ottoman Emirate: 1300-1389. Rethymnon, Crete University Press, 1993, pp. 77-99.

29. Laiou A. Constantinople and the Latins: The Foreign Policy of Andronicus II, 1282-1328. Cambridge (Mass.), Harvard University Press, 1972. XII, $390 \mathrm{p}$.

30. Lemerle P. L'Emirat d'Aydin Byzance et l'Occident. Paris, Presses universitaires de France, 1957.276 p.

31. Nicephori Gregorae Byzantina historia. In 3 vols. Vol. 1. Bonn, Weber, 1829. C, 568 p.

32. Nicol D.M. The Last Centuries of Byzantium, 1261-1453. London, Hart-Davis, 1972. XII, 482 p.

33. Nicol D.M. The End of the Byzantine Empire. London, E. Arnold, 1979. 109 p.

34. Nicol D.M. Byzantium and Venice: A Study in Diplomatic and Cultural Relations. Cambridge; New York, Cambridge University Press, 1988. X, 465 p.

35. Oikonomidès N. The Turks in Europe (1305-13) and the Serbs in Asia Minor (1313). Zachariadou E.A., ed. The Ottoman Emirate: 1300-1389. Rethymnon, Crete University Press, 1993, pp. 159-168.

36. Hussey J., Charanis P., eds. Ostrogorsky G. History of the Byzantine State. New Brunswick, N.J., Rutgers University Press, 1969. XL, 624 p.

37. Wittek P. Das Fürstentum Mentesche. Studie zur Geschichte Westkleinasiens im 13-15 Jahrhunderts. Istanbul, Universum Druckerei, 1934. XIV, 192 p.

38. Zachariadou E. Cortazzi kai ochi corsari [Cortazzi But Not Corsari]. Thēsaurismata [Thesaurismata], 1978, vol. 15, pp. 62-65. 
B.A. Золотовский. Византийская стратегия военных действий в Малой Азии

\section{Information About the Author}

Vladimir A. Zolotovskiy, Candidate of Sciences (History), Head of the Department of Service and Tourism, Volgograd State University, Prosp. Universitetsky, 100, 400062 Volgograd, Russian Federation, zolotovskiy.azi@volsu.ru, https://orcid.org/0000-0002-4259-8851

\section{Информация об авторе}

Владимир Алексеевич Золотовский, кандидат исторических наук, заведующий кафедрой сервиса и туризма, Волгоградский государственный университет, просп. Университетский, 100, 400062 г. Волгоград, Российская Федерация, zolotovskiy.azi@volsu.ru, https://orcid.org/0000-0002-4259-8851 